\title{
Multidrug Resistance-Associated Protein 4
}

National Cancer Institute

\section{Source}

National Cancer Institute. Multidrug Resistance-Associated Protein 4. NCI Thesaurus.

Code C103881.

Multidrug resistance-associated protein $4(1325 \mathrm{aa}, \sim 150 \mathrm{kDa}$ ) is encoded by the human ABCC4 gene. This protein plays a role in platelet degranulation, ATP hydrolysis and organic anion transport. 